\title{
Bank Performance in Profitability Dimensions: What External Factors and Why Does It Affect?
}

\author{
$1^{\text {st }}$ Ariyani Indriastuti \\ Doctorate of Management Programme \\ Diponegoro University \\ Semarang, Indonesia \\ ariyanindr@gmail.com
}

\author{
$2^{\text {nd }}$ Harjum Muharam \\ Doctorate of Management Programme \\ Diponegoro University \\ Semarang, Indonesia
}

\begin{abstract}
Performance in a company is an indicator of a company is working well or not, as well as banking. Bank performance is influenced by internal and external factors. Internal factors is a condition under the control of bank management, meanwhile external factors are outside the control of bank management. The dimensions of bank performance in this research focus on profitability and its influence from external factors. The profitability we use is RoA (Return on Assets) and RoE (Return on Equity). The purpose of this research is to make a basis for thinking and to find out how influential external factors in the macroeconomic realm are on bank performance in order to make effective and efficient solutions. The research method used is a literature study using secondary data from various journals and related articles. The results of the study explain that there are 3 (three) external factors that are often the topic of discussion, namely inflation, economic growth (GDP), and interest rates. Inflation does not really have an effect on RoE, but it does have an effect on RoA. On economic growth (GDP), RoE has a positive effect on GDP, as well as RoA which has a positive relationship. The interest rate also has a positive effect on RoE. Likewise with RoA which has a positive effect on interest rates. It is hoped that this research can become a reference in seeing what external factors in the macroeconomic can affect bank performance in terms of profitability.
\end{abstract}

Keywords: Bank performance, profitability, RoA (Return on Assets), RoE (Return on Equity), inflation, GDP, interest rates

\section{INTRODUCTION}

Today, banks are at the central of helping the wheels of an economic turnaround in every country, including Indonesia. According to Yuanita [1], The banking industry is one of the main sources of finance for the Indonesian economy. Banks have played many roles for economic sustainability, so it is not surprising that there are many studies on the banking sector and its mechanisms. The determinants of bank profitability and performance have been studied since the seventies. Researchers at that time considered bank-specific characteristics, industry-specific factors, and macroeconomic variables as the main determinants of bank profitability [2].
According to Law no. 10 of 1998 regarding banking, it is concluded that the banking business includes three activities, namely collecting funds from the public in the form of savings and channeling funds to the public in the form of credit or other forms to improve the standard of living of the community. Banks have a dominant role in the financial system.

In carrying out its activities, banks have benchmarks to measure whether a banking company is considered good or not. According to Jalal [3] the overall performance of the bank is a description of the achievements achieved by the bank in its operations, both regarding the aspects of finance, marketing, collection and distribution of funds, technology, and human resources.

Bank performance has 2 (two) factors, namely internal factors, and external factors. Internal factors are circumstances or events that are influenced by matters from within the bank itself and are still under the control of a bank's management. Many efforts have been made to strengthen bank internal governance, which is considered a key factor in explaining bank performance [4]. However, there are still differences in determining factors [5]. Meanwhile, external factors are the opposite of internal factors, which are influenced by things from outside the bank and are outside the management control of a bank. Each factor has its own risk in influencing the performance of a bank and can influence one another. External factors are riskier than internal factors because they are unpredictable and cannot be controlled arbitrarily by bank management. Therefore, many studies have taken the topic of these external factors. Then what external factors have a major influence on the performance of a bank, namely taken from the macroeconomic sector. The economic growth of a country, the inflation rate, and the interest rate are the factors that affect the bank's performance both in quality and quantity.

In measuring bank performance, the most appropriate measure is to measure the ability of banks to generate profits or profits from various activities carried out. In this paper, the dimension of bank performance that will be discussed more frequently is the increase in profitability. Profitability itself is the main defense to be able to face 
losses that can occur at any time in a bank. Profitability has a measure that is used as a proxy, namely RoA (Return on Assets) which is a measure of how effective a bank is to generate profits with existing assets, and RoE (Return on Equity) is a measure of the return obtained from investments of ordinary shareholders in a company. . The following is brainstorming of the topics to be raised to make it easier for readers to see the frame of mind and provide a general understanding.

This paper offers theoretically through various reference sources to provide an overview and know the effects that cause a bank's performance to rise or fall, considering this is used as an indicator of whether a company is working optimally or not. It is hoped that this paper can provide a new perspective to reduce risk and create effective and efficient solutions.

\section{LITERATURE REVIEW}

The performance of a company is a measure or indicator of whether a company can be said to be able to work well or not. In the performance systematics itself, there are many separate factors and indicators whether the company is said to be healthy or not so that many companies are active in analyzing, evaluating, and arranging strategies in the hope of improving the company's performance.

The same is the case with the banking sector. The bank itself makes the performance of a bank an indicator of whether the bank is healthy or not which is measured within a certain maturity or period. Assessment of a company's financial performance is one way that management can do to fulfill its obligations to funders and to achieve the goals set by the company. Bank financial performance is a description of the bank's financial condition in a certain period, both in terms of raising funds and channeling funds, which are usually measured by indicators of capital adequacy, liquidity, and bank profitability.

According to Rose [6] bank performance has two indicators, namely quality, and quantity, while the dimensions of bank performance are the dimensions of profitability and risk. Jalal also explains again that the measures used as a proxy for profitability are RoA (Return on Assets) and RoE (Return on Equity), while in the risk dimension the measures used as a proxy are LDR (Loans to Deposit Ratio) and CAR (Capital). Adequacy Ratio).

According to Gitman and Zutter [7], Profitability is the ability of a company to generate profits. Profitability is used as an indicator in measuring the performance of a bank. Companies that generate good profits or profits will invite and attract investors to invest their funds. Investors will see whether a company has financed in terms of good profits as well as healthy returns or returns. According to Taswan [8], the measurement of profitability at banks can use RoA and RoE.

RoA (Return on Assets) is the ability of a company to manage its assets to generate profits by prioritizing the level of effectiveness and efficiency of their use. RoA (Return on Assets) was chosen as an indicator for measuring financial performance because the RoA increases, the company's profitability also increases, so it can be said that the bank's financial performance is successful following the wishes and goals of shareholders and the company, namely increasing profitability [9].

RoE (Return on Equity) according to Gitman and Zutter is a measurement of the return obtained on the investment of ordinary shareholders in the company. Meanwhile, RoE (Return on Equity) according to Taswan is a ratio that measures a company's ability to generate net income from its equity capital.

External factors that affect the performance of a bank are from a macroeconomic perspective. Macroeconomics is the study of economics that deals with the broader economy. Because of its broad scope, macroeconomics often discusses the economy in a state and even its relationship with one country to another, both nationally and internationally.

Inflation in Alhayria, et al., [10] is a process of increasing prices in general and is continuously related to market mechanisms which can be caused by several factors such as increased public consumption, excess liquidity in the market that triggers consumption or speculation, until including the result of the improper distribution of goods. Inflation can be positive and negative depending on the impact it produces. Inflation is an endogenous variable that can respond to growth or other variables related to growth. For example, an inverse relationship between growth and inflation would arise if a slowdown in the growth rate exogenously tends to result in higher inflation.

Economic growth (GDP) in Lestari, H.S. and Aprilriani, G. [11] is measuring the market value of the final goods and services produced by resources that are in a country within a certain period, and usually one year. GDP can be defined as the value of goods and services produced by the production factors belonging to these citizens and foreign countries in a certain year. GDP was never designed to measure social or economic well-being, however, currently, GDP is the most commonly used indicator for a country's overall performance [12].

The interest rate according to Alhayria, et al.is a certain percentage that is calculated from the loan principal that must be paid by the debtor within a certain period and received by the creditor as a service fee. In macroeconomics, a country's interest rate affects investment attractiveness or interest. Badan and Lestari [13] stated that in macroeconomics, the interest rate is determined by the level of demand and supply in the market. The bank lending rate is expected to have a positive impact in terms of bank profitability.

\section{METHOD}

This paper draws several journals and articles both nationally and internationally from platforms that support research publications to seek related theories, collect data, and enrich the point of view of each reference author studied. A literature study is one of several research methodologies by conducting research or study through historical data. Because literature studies use historical data, the data used are usually the result of research and can be obtained from library sources or can be in the form of documents. In library research, a literature search is not only for the initial step of preparing a research framework (research design) but at the same time utilizing library sources to obtain research data. The advantage of using 
this research method is that the researcher only carries out a comparative or comparative study of each of the sources obtained and is associated with the desired theme or topic. Good analytical skills and persistence are needed in carrying out this methodology so that data retrieval can match the topics discussed.

In a study, there are two sources of data, namely primary data and secondary data. Primary data is research data using certain instruments and is only valid at a certain time according to when the research was made. Primary data cannot be generalized, usually, it is specific to the problem being raised. Secondary data itself is more generalizable and does not have a certain tempo. Secondary data is usually the result of a study that has been established and standardized in the form of a report or book. Secondary data are very susceptible to "bias" or subjectivity from the author because they do not carry out direct research that is more objective like primary data. In this paper, researchers use secondary data so that it can be more generalizable because this study is to provide an overview of an influence by looking at sources from previous research.

\section{RESULTS AND DISCUSSION}

Research conducted by the Agency and Lestari (2015) to analyze the significant influence between internal and macroeconomic factors such as Gross Domestic Product (GDP), interest rates, and consumer price inflation (CPI) by considering various problem formulations and historical customs of various studies. The research method is to test the historical data hypothesis to know the internal and macroeconomic factors that affect the profitability of a bank. The subject of analysis in this study using bank data that has been listed on the Indonesia Stock Exchange (BEI) and each bank has complete financial reports for the period 2009-2013. The results of the study by considering hypothesis testing and financial report data on banks in the macroeconomic aspect show that the interest rates on RoA and RoE have a positive and significant effect. This is because when the interest rate rises, the bank's income will increase and provide benefits to the bank. The income earned from interest also has a positive effect on bank interest and costs as well as net income, thus affecting bank profitability. Economic growth (GDP) also has a positive and significant effect on the results of RoA and RoE. Economic growth itself is related to supply and demand in the market, including in the banking sector. This has a direct effect on bank performance as measured by profitability. Furthermore, there is Consumer Price Inflation (CPI), in this study the CPI shows no significant effect on RoA and RoE. According to Alper and Anbar (2011) in the Agency, A. Y. A. and Lestari, H. S. (2015) stated that if the inflation rate is anticipated, banks can adjust the interest rate to increase revenue from fees. Conversely, if the inflation rate is not anticipated, the bank cannot make a proper adjustment of interest rates and fees can increase faster than income. Real interest rates have nothing to do with bank profitability.

Research on profitability was also carried out in Ghana by Doku, et al. [14] who examined the effect of capital structure on the profitability of commercial banks in Ghana. The results showed that the capital structure of a bank as measured by the ratio of capital to assets is a strong and positive driver for bank performance indicators (profitability).

In America, there is Hirtle, et al. [15] which examines the impact of surveillance on the risk, profitability, and growth of US banks with the result that the top-rated banks that receive more supervisory attention have loan portfolios that are lower risk, less volatile, and less sensitive to industrial downturns, but lacks growth or lower profitability.

Furthermore, there is research conducted by Javed, M. A. and Basheer, M. F. [16] to measure the impact of interest rates and economic growth on the profitability of banks in Pakistan. The study was conducted by taking annual data from several banks with a period from 2003 to 2013. The method used is regression analysis. For RoA on variable aspects in macroeconomics in Pakistan, models have been made through the theoretical and empirical literature. The results show that there is a positive relationship between interest rates and RoA. There is a level of $1 \%$ at a significant level. There is also a positive relationship between the level of economic growth of a country and the RoA. The results show that there is a number of $1 \%$ at a significant level.

Another study was conducted by Lestari, H. S., and Aprilriani, $\mathrm{G}$ to determine the influence of causal factors between internal and external factors on the performance effects of commercial banks in Indonesia. Here, more focus on RoE and EVA (Economic Value Added). The research method uses purposive sampling method by classifying the companies that will be the sample analysis according to the criteria that this researcher provides. The criteria are commercial banks that have gone public and are on the Indonesia Stock Exchange (IDX) from 20102014 with the population being banks that have complete financial reports and have a motivated EVA value from 2010 to 2014 . The results show that inflation does not have a direct effect on RoE because according to this researcher, investment given by investors or shareholders will decrease when inflation occurs so that shareholders are more interested in allocating their capital to other sectors with consideration of price and profit. High inflation rates can also lead to economic instability and uncertainty, which may increase the risk of a bank company. Economic growth (GDP) has a positive and significant effect on RoE. As we know, the better a country's economic growth, the better the bank's performance. One of the best indicators in assessing economic development is GDP (Mankiw, 2012).

Alhayria, et al. also researched to determine and analyze the effect of inflation and interest rates on RoA. The method used is a linear regression with secondary data. The population used in this study uses the financial statements of the banking sub-sector companies listed on the Indonesia Stock Exchange (BEI) with a total of 8 banks. The results showed that inflation has no effect on the RoA of a bank, as well as interest rates that have no effect on the RoA of a bank. Another unique result is that interest rates and inflation have a significant effect on RoA simultaneously.

The last research used as discussion material in this paper is that of Jaber, J. J. and Al-khawaldeh [17]. This study aims to determine the profitability of commercial banks in Jordan and analyze the things that affect the 
operational performance of commercial banks in Jordan from internal and external factors in companies listed on the Amman Stock Exchange in banks in Jordan from 2007 to 2012. Research this with a RoA focus. The results show that there is a significant influence on external factors, namely inflation divided by economic growth in Jordan.

\section{CONCLUSION}

Based on a literature review that has been linked to discussions from various journals, this paper takes the form of a hypothesis that economic growth (GDP) on RoE and RoA has a positive and significant effect. This is because the definition also looks at the functions within the bank itself as part of the economic wheel which has meaning in the economic growth of a country. Interest rates also have a positive and significant impact on the RoA and RoE of a bank. Inflation does not have a significant impact on RoE but affects RoA. And a unique fact obtained from one study in the discussion concluded that if inflation and interest rates work simultaneously, it can have a significant effect on the RoA of a bank.

The importance of bank profitability can be assessed at the micro and macroeconomic level. At the micro-level, profit is a basic prerequisite for competitive banking institutions and the cheapest source of funding. The basic objective of bank management is to achieve profit, which is a basic requirement for business development. At the macro level, the profitable banking sector is better able to withstand negative shocks and contribute to financial system stability.

For banking management, it would be good to frequently evaluate bank performance and find out the cause and effect of internal and external factors to create solutions and innovations to anticipate slack bank performance and improve bank performance properly. Investors will look to banks that have a healthy performance because this reflects conditions in the bank itself.

Investors are expected to carry out a fundamental analysis of the banks they want to target, one of which is by analyzing the bank's performance. This is done to reduce losses or other unpredictable things in the future. A good bank performance reflects the health of a bank unit, one of which is by looking at the bank's financial performance with the dimension of profitability. Be wise in determining which companies to allocate funds to invest in..

\section{ACKNOWLEDGMENT}

We thank our colleagues from Doctorate Program of Diponegoro University who become of the author affiliation.

\section{REFERENCES}

[1] Yuanita, N. (2019). Competition and bank profitability. Journal of Economic Structures, 8(31).

[2] Hamdi, H., Hakimi, A., \& Zaghdoudi, K. (2017). Diversification, bank performance and risk: have Tunisian banks adopted the new business model?. Financial innovation, 3(1), 22.

[3] Jalal, A. A. (n.d.). Pengaruh Makroekonomi, Pascasarjana Univeristas Indonesia, 16-49.
[4] Djebali, N., \& Zaghdoudi, K. (2020). Testing the governanceperformance relationship for the Tunisian banks: a GMM in system analysis. Financial Innovation, 6, 1-24.

[5] Lee, S. P., \& Isa, M. (2015). Directors' remuneration, governance and performance: the case of Malaysian banks. Managerial Finance. 41, 26-44

[6] Rose, C. (2016). Firm performance and comply or explain disclosure in corporate governance. European Management Journal, 34(3), 202-222.

[7] Gitman, L. J., \& Zutter, C. J. (2012). Principles of Managerial Finance. 13e. Aufl., Boston ua.

[8] Taswan, C., \& Si, M. (2010). Manajemen Perbankan. Yogyakarta: UPP STIM YKPN Yogyakarta.

[9] Purwoko, D., \& Sudiyatno, B. (maret, 2013). Faktor-Faktor Yang Mempengaruhi Kinerja Bank (Studi Empirik Pada Industri Perbankan di Bursa Efek Indonesia). Jurnal Bisnis dan Ekonomi (JBE), 20(1), 25-39

[10] Alhayria, A., Azaluddin, A., \& Mahmuda, D. (2019). Pengaruh Inflasi dan Suku Bunga terhadap Return on Asset (RoA) Bank yang Listing pada Bei. Entries, 1(1), 33-44.

[11] Lestari, H. S., \& Aprilriani, G. (2016). Pengaruh Faktor Internal dan Eksternal Bank terhadap Kinerja Keuangan pada Bank Umum di Indonesia. Kompetensi - Jurnal Manajemen Bisnis, 11(2), 95112.

[12] Kubiszewski, I., Costanza, R., Franco, C., Lawn, P., Talberth, J., Jackson, T., \& Aylmer, C. (2013). Beyond GDP: Measuring and achieving global genuine progress. Ecological Economics, 93, 5768.

[13] Badan, A. A., \& Lestari, H. S. (2015). Faktor - Faktor Yang Mempengaruhi Profitabilitas Bank Yang Terdaftar di Bursa Efek Indonesia. Seminar Nasional Cendekiawan, 640-652.

[14] Doku, J. N., Kpekpena, F. A., \& Boateng, P. Y. (2019). Capital Structure and Bank Performance: Empirical Evidence from Ghana. African Development Review, 31(1), 15-27.

[15] Hirtle, B., Kovner, A., \& Plosser, M. (2020). The impact of supervision on bank performance. The Journal of Finance, 75(5), 2765-2808.

[16] Javed, M. A., \& Basheer, M. F. (2017). Impact of External Factors on Bank Profitability. EPRA International Journal of Research and Development (IJRD), 2(5). 